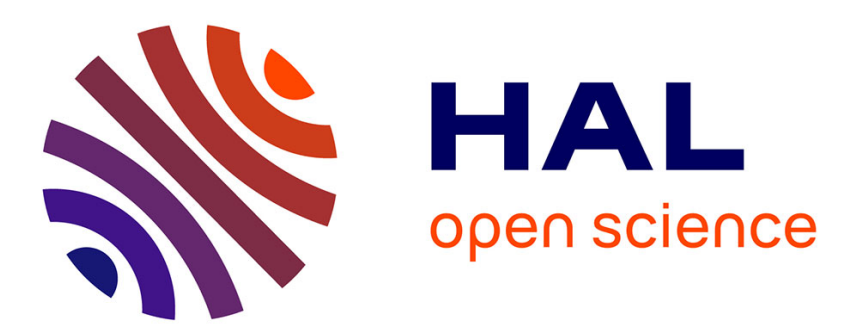

\title{
Isolation and synthesis of pygmanilines, phenylurea derivatives from the Northeastern Atlantic lichen Lichina pygmaea
}

Nipun Mahajan, Rekha Chadda, Kevin Calabro, Hiren Solanki, Enda O' Connell, Paul Murphy, Olivier P. Thomas

\section{To cite this version:}

Nipun Mahajan, Rekha Chadda, Kevin Calabro, Hiren Solanki, Enda O' Connell, et al.. Isolation and synthesis of pygmanilines, phenylurea derivatives from the Northeastern Atlantic lichen Lichina pygmaea. Tetrahedron Letters, 2017, 58 (12), pp.1237-1239. 10.1016/j.tetlet.2017.02.037 . hal01854036

\section{HAL Id: hal-01854036 https://hal.science/hal-01854036}

Submitted on 9 Dec 2019

HAL is a multi-disciplinary open access archive for the deposit and dissemination of scientific research documents, whether they are published or not. The documents may come from teaching and research institutions in France or abroad, or from public or private research centers.
L'archive ouverte pluridisciplinaire HAL, est destinée au dépôt et à la diffusion de documents scientifiques de niveau recherche, publiés ou non, émanant des établissements d'enseignement et de recherche français ou étrangers, des laboratoires publics ou privés. 


\title{
Isolation and synthesis of pygmanilines, phenylurea derivatives from the Northeastern Atlantic lichen Lichina pygmaea
}

\author{
Nipun Mahajan ${ }^{\mathrm{a}}$, Rekha Chadda ${ }^{\mathrm{a}}$, Kevin Calabro $^{\mathrm{b}}$, Hiren Solanki ${ }^{\mathrm{a}}$, Enda O' Connell ${ }^{\mathrm{c}}$, Paul V. Murphy ${ }^{\mathrm{a}}$ and \\ Olivier P. Thomas*,a \\ ${ }^{a}$ National University of Ireland Galway, School of Chemistry, University Road, Galway, Ireland \\ ${ }^{b}$ Université Côte d'Azur, CNRS, OCA, IRD, Géoazur, 250 rue Albert Einstein, 06560 Valbonne, France \\ ${ }^{c}$ National University of Ireland Galway, NCBES, University Road, Galway, Ireland
}

\begin{abstract}
A library of 864 extracts prepared from Irish marine organisms was screened in the search for novel antioxidants. Chemical investigation of the most promising extract obtained from the common lichen Lichina pygmaea led to the isolation of five resorcinol derivatives. An unusual urea moiety was found embedded in two of these compounds, pygmanilines A (1) and B (2) and their structures were confirmed by one-step chemical syntheses.
\end{abstract}

The marine environment is recognized today as an untapped reservoir of biodiversity associated with an extraordinary chemical diversity with high potential in different industrial sectors. ${ }^{1}$ The ability of marine invertebrates and their microbial symbionts to biosynthesize unique chemical architectures makes them attractive candidates to find new bioactive molecules, especially of pharmaceutical interest. ${ }^{2}$ The discovery of such small molecules followed by their total synthesis is a key step to uncover new products for this industry. In this context, we explored the potential of marine organisms present in Irish waters as they have been poorly investigated. In the framework of the Irish funded Beaufort Programme, marine invertebrates such as sponges, ascidians, bryozoans, lichens, and cnidarians were collected from intertidal and subtidal zones of the Northeastern Atlantic Ocean. Small portions of each macro-organism were used to isolate and grow some associated microbes using different types of agar containing media leading to 864 extracts in total. ${ }^{3,4}$ These extracts were screened to determine their Trolox Equivalent Antioxidant activity (TEAC) using a simple robust and cell-free decolorization assay utilising 2,2'-azino-bis(3-ethylbenzothiazoline-6-sulfonic acid) (ABTS) dye. The main result of this quick antioxidant screening underlined the extract of the lichen Lichina pygmaea as the most promising hit among 864 extracts, therefore it was further chemically investigated. (See ESI).

Lichina pygmaea is a lichen commonly encountered in the intertidal zones of the Northeastern Atlantic Ocean. It is constituted by a mycobiont associated to a cyanobacterium Rivularia sp. ${ }^{5,6}$ The few chemical studies performed on this species have revealed the presence of a polysaccharide. ${ }^{7}$ Then, the mycosporin-like amino acid (MAA) mycosporine serinol and a glutamic acid aryl hydrazide were isolated by Rouiller and co-workers. from this species using multiple dual-mode centrifugal partition chromatography. ${ }^{8}$ In the same year a second MAA, M-gly, was identified in this species on the basis of HPLC co-elution. ${ }^{9}$ Later, an

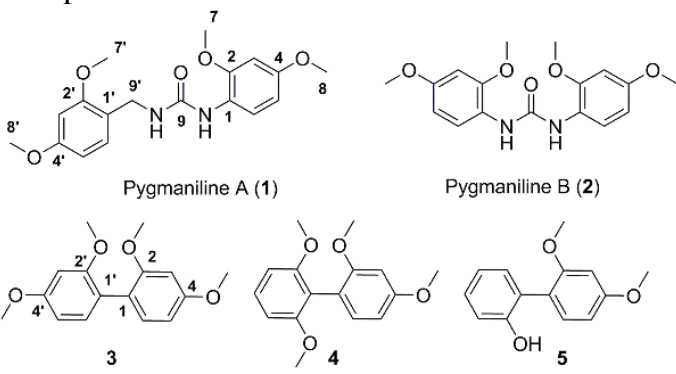

additional aryl hydrazide active against melanoma cell lines was identified and characterized. ${ }^{10}$ The two MAAs M-Gly and porphyra-334, isolated from a red alga, are capable of reducing ABTS dye and are patented as antioxidants due to their ability to inhibit lipid oxidation. ${ }^{11,12}$ Herein, the chemical investigation of an Irish specimen of this species led to the isolation of five new 
resorcinol derivatives 1-5, among which two of them included an unusual urea moiety (Fig. 1). Also, the known compounds $2,2^{\prime}, 5,5^{\prime}$-tetramethoxybiphenyl (6), ${ }^{13}$ L-pyroglutamic acid methyl ester (7) ${ }^{14}$ and isoaucuparin $(\mathbf{8}),{ }^{15}$ were isolated together with the major ergosterol peroxide (9). ${ }^{16}$

Figure 1. Structures of the new metabolites isolated from L. pygmaea

A hydrophilic extract of the Irish lichen Lichina pygmaea was prepared using a mixture of $\mathrm{MeOH} / \mathrm{H}_{2} \mathrm{O}$ (1:1). After fractionation on Sephadex LH20, a second process was applied by $\mathrm{C}_{18}$ reversed phase vacuum liquid chromatography using a gradient elution of $\mathrm{H}_{2} \mathrm{O}-\mathrm{MeOH}$ from 100:0 to 0:100 (v/v). The $\mathrm{H}_{2} \mathrm{O} / \mathrm{MeOH}(1: 1)$ fraction was dissolved in a mixture of $\mathrm{H}_{2} \mathrm{O} / \mathrm{MeOH}^{-\mathrm{NH}} \mathrm{H}_{4} \mathrm{OH}(9: 0.9: 0.1)$ and extracted with $\mathrm{CHCl}_{3}$. This lipophilic fraction was further purified by successive reversed phase HPLC.

Compound 1 was isolated as an amorphous brown solid with the molecular formula $\mathrm{C}_{18} \mathrm{H}_{22} \mathrm{~N}_{2} \mathrm{O}_{5}$ as established by HRMS analysis with $\mathrm{m} / \mathrm{z}$ at $347.1599\left([\mathrm{M}+\mathrm{H}]^{+}, \Delta-0.6 \mathrm{ppm}\right)$. The ${ }^{1} \mathrm{H}$ NMR spectrum obtained in $\mathrm{CD}_{3} \mathrm{OD}$ highlighted the phenolic nature of the compound with six signals in the aromatic region, four of them being shielded at around $\delta_{\mathrm{H}} 6.5$. As per the multiplicity and integration of each aromatic signal, the two constitutive benzene rings were deduced to be ortho/para trisubstituted. Also, the ${ }^{1} \mathrm{H}$ NMR spectrum revealed the presence of four methoxy groups, therefore inducing the observed shielding of four aromatic protons. The third and last substituents on each ring were clearly distinct as the corresponding hydrogens at the C-6 and C-6' ortho positions possess different signals at $\delta_{\mathrm{H}} 7.67(\mathrm{~d}, J=8.5 \mathrm{~Hz}, 1 \mathrm{H}, \mathrm{H}-6)$ and $7.16(\mathrm{~d}, J=8.5 \mathrm{~Hz}, 1 \mathrm{H}, \mathrm{H}-6$ ') (Table 1). The presence of a methylene substituted on the second aromatic ring was evidenced by a signal at $\delta_{\mathrm{H}} 4.26$ (s, 2H, H-9') and the key H-9'/C-1', C-2', C-

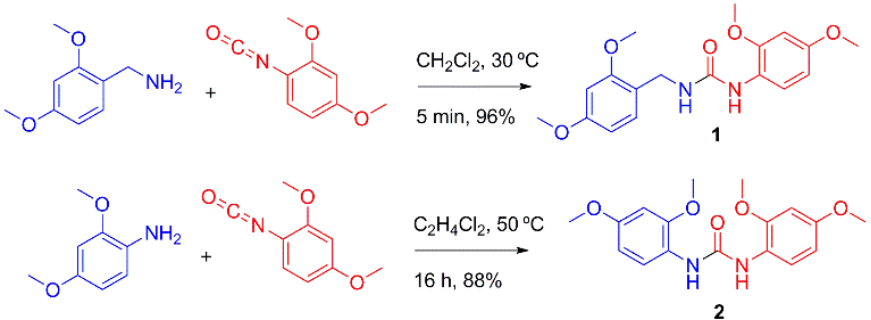

6' and H-6'/C-9' HMBC correlations. The connection between the two parts of the molecule was not straightforward, and the molecular formula was used to suggest the presence of urea as a central and connective functional group. This postulate was supported by the additional H-9'/C-9 and H-6/C-9 key HMBC correlations. The ${ }^{1} \mathrm{H}$ NMR spectrum of 1 performed in DMSO- $d_{6}$ evidenced two additional signals corresponding to the non-equivalent $\mathrm{N}-\mathrm{H}$ 's: a signal at $\delta_{\mathrm{H}} 6.85(\mathrm{t}, J=5.5 \mathrm{~Hz}, 1 \mathrm{H}, \mathrm{N}-\mathrm{H} 1$ ') which was COSY correlated to the signal corresponding to $\mathrm{H}_{-} 9^{\prime}$ ' and a signal at $\delta_{\mathrm{H}} 7.76(\mathrm{~s}, 1 \mathrm{H}, \mathrm{N}-\mathrm{H} 1)$ assigned to the aniline part of the urea functional group. This new compound was named pygmaniline A.

Table 1: ${ }^{1} \mathrm{H}$ and ${ }^{13} \mathrm{C}$ NMR data of compounds $\mathbf{1 - 2}$ in $\mathrm{CD}_{3} \mathrm{OD}$ at $500 \mathrm{MHz}$ and $125 \mathrm{MHz}$ respectively $\left[\delta_{\mathrm{H}}\right.$ in ppm, mult. $(J$ in $\mathrm{Hz})$ and, $\delta_{\mathrm{C}}$ in ppm]

\begin{tabular}{|c|c|c|c|c|}
\hline & 1 & & 2 & \\
\hline No. & $\delta_{\mathrm{H}}$ & $\delta_{\mathrm{C}}$ & $\delta_{\mathrm{H}}$ & $\delta_{\mathrm{C}}$ \\
\hline 1 & - & 123.0 & - & 122.7 \\
\hline 2 & - & 152.1 & - & 152.3 \\
\hline 3 & $6.54, \mathrm{~d}(2.5)$ & 99.7 & $6.57, \mathrm{~d}(2.5)$ & 99.7 \\
\hline 4 & - & 157.6 & - & 157.8 \\
\hline 5 & 6.45 , dd $(8.5,2.5)$ & 105.1 & $6.48, \mathrm{dd}(8.5,2.5)$ & 105.1 \\
\hline 6 & $7.67, \mathrm{~d}(8.5)$ & 122.8 & $7.74, \mathrm{~d}(8.5)$ & 123.0 \\
\hline 7 & $3.82, \mathrm{~s}$ & 56.2 & $3.87, \mathrm{~s}$ & 56.3 \\
\hline 8 & $3.76, \mathrm{~s}$ & 55.9 & $3.78, \mathrm{~s}$ & 55.9 \\
\hline 9 & - & 158.9 & - & 156.5 \\
\hline 1 ' & - & 120.9 & & \\
\hline 2' & - & 159.8 & & \\
\hline 3' & $6.53, \mathrm{~d}(2.5)$ & 99.3 & & \\
\hline 4' & - & 161.9 & & \\
\hline 5 ' & $6.46, \mathrm{dd}(8.5,2.5)$ & 105.1 & & \\
\hline 6 ' & $7.16, \mathrm{~d}(8.5)$ & 130.5 & & \\
\hline 7 ' & $3.84, \mathrm{~s}$ & 55.8 & & \\
\hline 8' & $3.78, \mathrm{~s}$ & 55.8 & & \\
\hline 9' & $4.26, \mathrm{~s}$ & 39.9 & & \\
\hline
\end{tabular}

Compound 2 was isolated as an amorphous brownish solid with the molecular formula $\mathrm{C}_{17} \mathrm{H}_{20} \mathrm{~N}_{2} \mathrm{O}_{5}$ as established by HRMS analysis with $\mathrm{m} / \mathrm{z}$ at $333.1453\left([\mathrm{M}+\mathrm{H}]^{+} \Delta 2.4 \mathrm{ppm}\right)$. In contrast with compound $\mathbf{1}$, the ${ }^{1} \mathrm{H}$ NMR spectrum of 2 suggested the presence of symmetry in the molecule. While the signals corresponding to the first benzene ring of $\mathbf{1}$ and especially the characteristic signal at $\delta_{\mathrm{H}} 7.74(\mathrm{~d}, J=8.5 \mathrm{~Hz}, 2 \mathrm{H}, \mathrm{H}-6)$ in the ortho position to the nitrogen were also present in 2 , the signal corresponding to the second ortho proton at $\delta_{\mathrm{H}} 7.16$ was not observed (Table 1). Together with the absence of the signal for the benzylic methylene of $\mathbf{1}$, this observation suggested that 2 was the corresponding symmetric 1,1'-bisaryl urea derivative. The substitution pattern around the benzene rings was found to be identical to compound $\mathbf{1}$ based on similar chemical shifts of the ${ }^{1} \mathrm{H}$ and ${ }^{13} \mathrm{C}$ NMR signals. Although this compound is new as a natural product it has already been synthesized in a laboratory. ${ }^{17}$ 
Natural products including urea moieties between two aromatic rings are extremely rare; therefore, we decided to confirm the structure of this compound by their total synthesis. After several attempts, we discovered that a single step reaction between an isocyanate derivative and the corresponding amine (for 1) or aniline (for 2) led to the targeted compounds in high yields (Scheme 1). Comparison of the ${ }^{1} \mathrm{H}$ NMR spectra in DMSO- $d_{6}$ with those of the natural products served as final confirmation of the structure of both unusual natural products.

Scheme 1. Syntheses of pygmaniline A (1) and pygmaniline B (2)

Compound 3 was isolated as a brown amorphous solid with the molecular formula $\mathrm{C}_{16} \mathrm{H}_{18} \mathrm{O}_{4}$ as established by HRMS analysis with $\mathrm{m} / \mathrm{z}$ at $275.1277\left([\mathrm{M}+\mathrm{H}]^{+} \Delta-0.4 \mathrm{ppm}\right)$. The ${ }^{1} \mathrm{H}$ NMR spectrum of $\mathbf{3}$ was very similar that of $\mathbf{2}$ except for the shielding of the $\mathrm{H}-$ 6 doublet from $\delta_{\mathrm{H}} 7.74$ in $\mathbf{2}$ to $\delta_{\mathrm{H}} 7.00$ in $\mathbf{3}$ (Table 2). This shielding was likely to be attributed to a change in the chemical moiety of the bridge between the two resorcinol rings. Using the molecular formula as evidence, a simple symmetric biaryl system was deduced as 2,2',4,4'-tetramethoxybiphenyl (3). Although this compound has been obtained by synthesis, ${ }^{18}$ to the best of our knowledge, it is the first description of $\mathbf{3}$ as a natural product. A similar structure was proposed in a PhD thesis but NMR data were not fully consistent. ${ }^{19}$

Compound 4 was isolated as a brown amorphous solid with the same molecular formula $\mathrm{C}_{16} \mathrm{H}_{18} \mathrm{O}_{4}$ with $\mathrm{m} / \mathrm{z}$ at 275.1286 $\left([\mathrm{M}+\mathrm{H}]^{+} \Delta 2.9 \mathrm{ppm}\right)$. Compounds $\mathbf{3}$ and $\mathbf{4}$ are therefore isomers due to a change in the substitution pattern around the benzene rings. The ${ }^{1} \mathrm{H}$ NMR spectrum of $\mathbf{4}$ revealed the loss of symmetry observed for $\mathbf{2}$ and $\mathbf{3}$ (Table 2). The first resorcinol of $\mathbf{4}$ was found to exhibit the same substitution pattern in the ortho/para positions as for $\mathbf{3}$ while in the second resorcinol ring a triplet at $\delta_{\mathrm{H}} 7.24$ suggested an ortho/meta substitution pattern. HMBC correlations confirmed this new substitution pattern. This is the first report of compound 2,2',4,6'-tetramethoxybiphenyl (4) as a natural product, however, it has been described as a degradation product of lichen polyketides. ${ }^{20}$

Compound 5 was isolated as a brown amorphous solid with the molecular formula $\mathrm{C}_{14} \mathrm{H}_{14} \mathrm{O}_{3}$ as established by HRMS analysis with $\mathrm{m} / \mathrm{z}$ at $231.1015\left([\mathrm{M}+\mathrm{H}]^{+} \Delta-0.4 \mathrm{ppm}\right)$. The ${ }^{1} \mathrm{H}$ NMR spectrum of $\mathbf{5}$ revealed an absence of symmetry in the molecule but also for the first time the presence of only two methoxy groups (Table 2). Upon comparison with the previous compounds, we quickly deduced that although the first ortho/para resorcinol ring was still present, the second ring exhibited a different substitution pattern. Indeed, four aromatic protons with multiplicities $\mathrm{d}, \mathrm{t}, \mathrm{t}$, $\mathrm{d}$ were consistent with a di-substituted ring, and the presence of an additional quaternary carbon at $\delta_{\mathrm{C}} 155.7$ (C-2') was indicative of an ortho-substituted phenol. Interestingly this new natural product 2'-hydroxy-2,4-dimethoxybiphenyl (5) has already been obtained by synthesis and was found to inhibit the VEGFA-165 protein secretion ${ }^{21}$.

Table 2. ${ }^{1} \mathrm{H}$ and ${ }^{13} \mathrm{C}$ NMR data of compounds 3-5 in $\mathrm{CD}_{3} \mathrm{OD}$ at $500 \mathrm{MHz}$ and $125 \mathrm{MHz}$ respectively $\left[\delta_{\mathrm{H}}\right.$ in ppm, mult. $\left(J\right.$ in $\mathrm{Hz}$ ) and $\delta_{\mathrm{C}}$ in ppm]

\begin{tabular}{|c|c|c|c|c|c|c|}
\hline No. & & & 4 & & 5 & \\
\hline 1 & - & 121.9 & - & 121.9 & - & 121.6 \\
\hline 2 & - & 159.6 & - & 159.9 & - & 159.3 \\
\hline 3 & $\begin{array}{c}6.55, \mathrm{~d} \\
(2.5)\end{array}$ & 99.7 & $\begin{array}{c}6.56, \mathrm{~d} \\
(2.5)\end{array}$ & 99.7 & 6.61, br s & 99.8 \\
\hline 4 & - & 161.6 & - & 161.7 & - & 162.0 \\
\hline 5 & $\begin{array}{c}6.52, \mathrm{dd} \\
(8.5,2.5)\end{array}$ & 105.5 & $\begin{array}{c}6.52, \mathrm{dd} \\
(8.5,2.5)\end{array}$ & 105.6 & $\begin{array}{c}6.58, \mathrm{brd} \\
(8.5)\end{array}$ & 106.0 \\
\hline 6 & $\begin{array}{c}7.00, \mathrm{~d} \\
(8.5)\end{array}$ & 132.9 & $\begin{array}{c}6.91, \mathrm{~d} \\
(8.5)\end{array}$ & 133.5 & $\begin{array}{c}7.11, \mathrm{~d} \\
(8.5)\end{array}$ & 133.1 \\
\hline 7 & $3.70, \mathrm{~s}$ & 56.0 & $3.67, \mathrm{~s}$ & 56.2 & $3.76, \mathrm{~s}$ & 56.1 \\
\hline 8 & $3.81, \mathrm{~s}$ & 55.8 & $3.82, \mathrm{~s}$ & 55.8 & $3.83, \mathrm{~s}$ & 55.8 \\
\hline 1 ' & & & - & 117.9 & - & 127.3 \\
\hline 2' & & & - & 159.8 & - & 155.7 \\
\hline 3 ' & & & $\begin{array}{c}6.66, \mathrm{~d} \\
(8.5)\end{array}$ & 105.5 & $\begin{array}{c}6.84, \mathrm{~d} \\
(7.5)\end{array}$ & 116.7 \\
\hline $4^{\prime}$ & & & $\begin{array}{c}7.24, \mathrm{t} \\
(8.5)\end{array}$ & 129.6 & $\begin{array}{l}\text { 7.13, br t } \\
\text { (7.5) }\end{array}$ & 129.1 \\
\hline 5 & & & $\begin{array}{c}6.66, \mathrm{~d} \\
(8.5)\end{array}$ & 105.5 & $\begin{array}{c}6.84, \mathrm{t} \\
(7.5)\end{array}$ & 120.5 \\
\hline $6^{\prime}$ & & & $\begin{array}{ll}- \\
-\end{array}$ & 159.8 & $\begin{array}{c}7.07, \mathrm{~d} \\
(7.5)\end{array}$ & 132.7 \\
\hline 7 & & & $3.66, \mathrm{~s}$ & 56.3 & & \\
\hline 8 ' & & & $3.66, \mathrm{~s}$ & 56.3 & & \\
\hline
\end{tabular}

All five new compounds were tested for their TEAC, in which $\mathbf{1}$ was found to exhibit potent antioxidant activity at low concentrations (Fig. 2). Also, compounds $\mathbf{5}$ and $\mathbf{2}$ showed concentration dependent antioxidant activity.

Figure 2. Trolox Equivalent Antioxidant capacity of compounds 1-5. 
An Irish marine extract library was prepared and screened to find the most promising extract with antioxidant capacity. Identified as a hit organism, the lichen Lichina pygmaea was chemically investigated which led to the isolation of five resorcinol derivatives, among which pygmaniline A (1) and pygmaniline B (2) bearing an unusual urea moiety were identified as promising antioxidant compounds. A one-step and efficient synthesis of both natural products was achieved to confirm the structure of the compounds. Interestingly, both pygmanilines include 2,4-dimethoxyaniline as a precursor. The same precursor can be identified in other analogues isolated from the same lichen such as aryl-hydrazides. In the case of pygmanilines we can assume a condensation of the nucleophilic nitrogen with a carbonyl group while an oxidative coupling with an amino-acid derivative is likely to occur for the aryl hydrazides. Due to the facility to produce these compounds in quantity and the absence of cytotoxicity they represent potential candidates for future investigations as natural antioxidant agents.

\section{Acknowledgments}

We would like to acknowledge the financial support from the Beaufort Programme and the National Marine Biodiscovery Laboratory (PBA/MB/16/01 Marine Institute, Galway, Ireland). NM received James Hardiman Research Scholarship (NUI Galway). We also thank R. Doohan for help in the record of the NMR spectra, B. Baker for advice in the construction of the extracts library and H. Fearnhead for advice in the ABTS based antioxidant screening.

\section{Supplementary Material}

Screening bioassay details as well as NMR and MS data for 1-5. Supplementary data associated with this article can be found, in the online version, at

\section{References and notes}

1 Blunt, J. W.; Copp, B. R.; Keyzers, R. A.; Munro, M. H. G.; Prinsep, M. R. Nat. Prod. Rep. 2016, $33,382$.

2 Martins, A.; Vieira, H.; Gaspar, H.; Santos, S. Mar. Drugs 2014, 12, 1066.

3 Joint, I.; Muehling, M.; Querellou, J. Microb. Biotechnol. 2010, 3, 564.

$4 \quad$ Kjer, J.; Debbab, A.; Aly, A. H.; Proksch, P. Nat. Protoc. 2010, 5, 479.

5 Ortiz-Alvarez, R.; de los Rios, A.; Fernandez-Mendoza, F.; Torralba-Burrial, A.; Perez-Ortega, S. PLoS One 2015,10 , e0132718.

$6 \quad$ Peveling, E. Z. Naturforsch., B: Chem. Sci. 1972, 27, 1388.

7 Prieto, A.; Leal, J. A.; Bernabe, M.; Hawksworth, D. L. Mycol. Res. 2008, 112, 381.

$8 \quad$ Roullier, C.; Chollet-Krugler, M.; Bernard, A.; Boustie, J. J. Chromatogr. B 2009, 877, 2067.

9 De la Coba, F.; Aguilera, J.; Figueroa, F. L.; de Galvez, M. V.; Herrera, E. J. Appl. Phycol. 2009, $21,161$.

10 Roullier, C.; Chollet-Krugler, M.; van de Weghe, P.; Lohezic-Le Devehat, F.; Boustie, J. Bioorg. Med. Chem. Lett. 2010, 20,

4582 .

11 2007.

12 De la Coba, F.; Aguilera Arjona, J.; Lopez Figueroa, F. In Use of a mycosporin-type amino acid (m-gly) as an antioxidant,

De la Coba, F.; Aguilera, J.; Figueroa, F. In Use of mycosporine-type amino acid Porphyra-334 as an antioxidant, International, International, 2007; Vol. WO2007026036.

$13 \quad$ Naya, Y.; Kotake, M. Nippon Kagaku Zasshi 1965, 86, 313.

14 Chen, Q.-w.; Tian, Y.; Chen, H.-w.; Gao, T.; Dong, J.-x. Junshi Yixue 2014, 38, 62.

15 Kim, K. H.; Choi, S. U.; Ha, S. K.; Kim, S. Y.; Lee, K. R. J. Nat. Prod. 2009, 72, 2061

16 Hsiao, P.-Y.; Lee, S.-J.; Chen, I.-S.; Hsu, H.-Y.; Chang, H.-S. Phytochemistry 2016, 1.

17 Knoelker, H.-J.; Braxmeier, T.; Schlechtingen, G. Synlett 1996, 502.

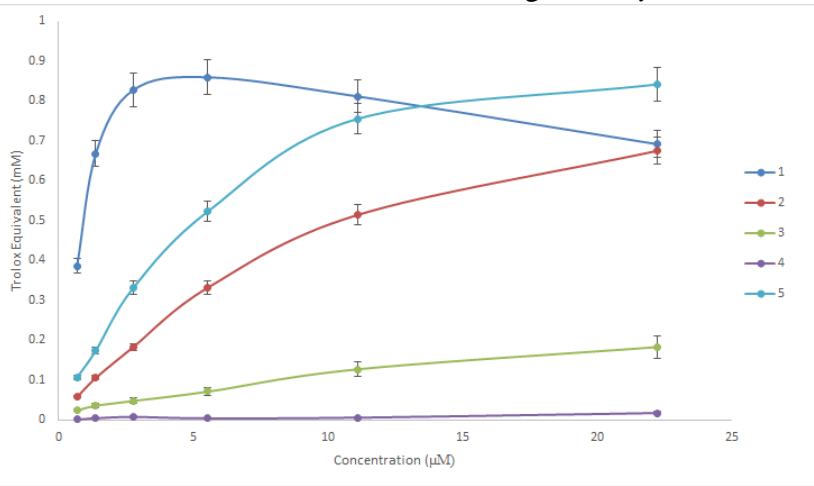

18 Bhattacharjya, A.; Klumphu, P.; Lipshutz, B. H. Nat. Commun. 2015, 6.

19 Roullier, C. In Recherche de mycosporines et de dérivés aminés lichéniques d'intérêt pour les cancers photoinduits. Etude phytochimique d'un lichen marin : Lichina pygmaea (Lightf.) C. Agardh.; Boustie, J. Ed.; Universite Rennes 1, Rennes, 2010; Vol. PhD. pp 262.

Wachtmeister, C. A. Acta Chem. Scand. 1954, 8, 1433.

21 Sanchez-Peris, M.; Falomir, E.; Murga, J.; Carda, M.; Marco, J. A. Biorg. Med. Chem. 2016, 24, 3108. 